\title{
THE INFLUENCE OF WATER HARDNESS ON GIANT FRESHWATER PRAWN (Macrobracbium rosenbergii de Man) SPAWNING AND EGG PRODUCTION
}

\author{
M. Fatuchri Sukadi*)
}

\begin{abstract}
The influence of water hardness on spawning and egg production of giant freshwater prawn, Macrobrachium rosenbergii de Man was investigated in indoor tanks during a 132 day study. Water hardness levels of 18,150 and $300 \mathrm{mg} / 1$ as $\mathrm{CaCO}_{3}$ were used as treatment levels.

There was no evidence that the number of spawnings, the spawning frequency of individual prawns, or the number of eggs per gram of female was influenced by water hardness ( $P>0.05)$. The number of early-stage eggs per gram of female (epgf) (721) was significantly higher than late-stage eggs $(475)(\mathrm{P}<0.05)$. There was no interaction between egg stage and water hardness on the epgf. However, there was an effect of water hardness on egg size and egg calcium $(P<0.05)$. Early-stage eggs were similar in size for all hardness levels, ranging from 0.57 to $0.58 \mathrm{~mm}$ in diameter. Late-stage eggs decreased from 0.68 to $0.63 \mathrm{~mm}$ in diameter as water hardness increased from 18 to $300 \mathrm{mg} / 1$ $(\mathrm{P}<0.05)$. Calcium content changed quadratically with water hardness in both early- and late-stage eggs $(\mathrm{P}<0.05)$.
\end{abstract}

KEYWORDS: Water hardness, giant freshwater prawn, spawning, egg production, Macrobracbium rosenbergii

\section{Introduction}

Acceptable levels for culturing giant freshwater prawns, Macrobrachium rosenbergii de Man have been determined for temperature, dissolved oxygen, ammonia, nitrite, and $\mathrm{pH}$ (Sandifer and Smith 1985). Information on tolerance to, or the desirable levels of total water hardness for prawn spawning and egg production is less well defined.

Calcium and magnesium ions are the major component of total water hardness (Boyd 1984). Robertson (1941) stated that the calcium content of natural waters varies from less than $1 \mathrm{mg} / 1$ in acid peaty waters to greater than $400 \mathrm{mg} / 1$ in alkaline water. Calcium is an essential constituent of protoplasm and body fluids of all animals. Divalent calcium ions stabilize intercellular matrices, cell surfaces and mucous coverings (Robertson 1941). In a study of

") Researcher at Research Institute for Marine Fisheries, Jakarta 
echinoderm eggs, the hyaline layer did not form on the surface of eggs while the matrix holding the cells of developing larvae was dispersed in calcium-free water. Normal development of sponge and echinoderm larvae and their skeletal structures were also impaired or retarded by a lack of calcium in the water (Robertson 1941).

In oviparous organisms such as freshwater prawns, the mother and eggs are completely separated in both time and space. Simkiss (1967) suggested that there must be a storage systems of calcium in the reproductive process into which the mother can deposite calcium and from which the embryo can withdraw calcium as it is required. In higher vertebrates such as birds, the source of calcium for embryo development is obtained from the yolk and egg shell (Jenkins and Simkiss 1968).

In a study on eggs of the Atlantic salmon (Salmo salar), data were obtained which indicated that the developing embryo could obtain calcium from the environment during development (Hayes et al. 1946). There should be a source of calcium for the embryo and a capability of the embryo to utilize the calcium at the rate required in order to mineralize the embryonic skeleton (Simkiss 1967). There is no information available concerning the influence of calcium on reproductive capacities, egg production and embryonic development of prawns.

This experiment was conducted to determine the influence of total water hardness on spawning rate and egg production in freshwater prawn (Macrobrachium rosenbergii). The results of the study should be useful when considering sites for culture and seed production procedures for prawns in regions with varying water hardness.

\section{Materials and Methods}

Mature prawn broodstock were maintained in three levels of water hardness for 132 days. The three levels of water hardness utilized in the study were: 18 $\mathrm{mg} / 1\left(7.4 \mathrm{mg} / 1 \mathrm{Ca}^{++}\right), 150 \mathrm{mg} / 1\left(56.1 \mathrm{mg} / 1 \mathrm{Ca}^{++}\right)$and $300 \mathrm{mg} / 1$ as $\mathrm{CaCO}_{3}$ $\left(109.9 \mathrm{mg} / 1 \mathrm{Ca}^{++}\right)$. These hardness levels were prepared by adding agricultural gypsum, $\mathrm{CaSO}_{4} \cdot 2 \mathrm{H}_{2} \mathrm{O}$, to well water. Agricultural gypsum is fairly soluble in water and can be used to increase calcium concentrations and total water hardness (Boyd and Wu 1989). The well water used in the study had an initial hardness of $18 \mathrm{mg} / 1$. No gypsum was needed to obtain the low level of hardness. The three treatment levels, each with three replicates, were randomly assigned to one of nine $1.4-\mathrm{m}^{3}$ fiberglass tanks.

Each tank was equipped with a gravel biofilter and two air lift pumps for filtration and aeration. Nine polyvinyl mesh bags were suspended in each tank to provide additional vertical substrate for the prawn (Figure 1). 


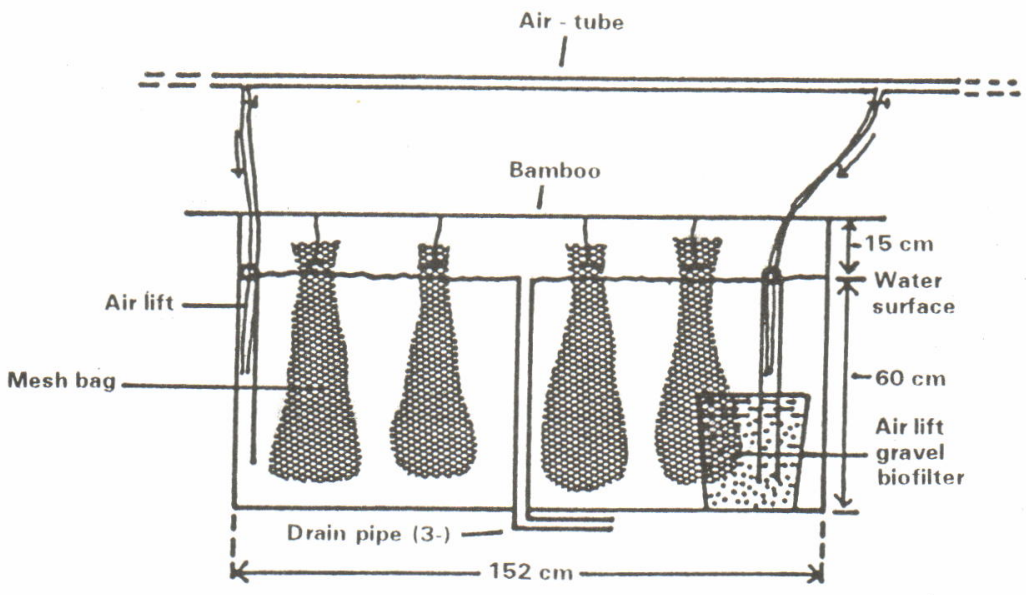

Figure 1. Fiberglass spawning tank for maintaining prawn broodstock.

Each tank received 30 females and 20 males to provide a female to male ratio of $3: 2$. This ratio was maintained throughout the experiment by replacing dead prawns with replacement taken from a prawn reserve tank. Prawn broodstock weighed between 10 and $34 \mathrm{~g}$ and were 5 months old when the experiment began. All broodstock had been obtained from production ponds. A commercial shrimp feed with $40 \%$ protein content was used to feed prawns once a day in ad libitum throughout the experiment.

Tanks were siphoned and approximately $20 \%$ make-up water was added weekly. A pH level near 7.0 was maintained throughout the study by adding $\mathrm{NaHCO}_{3}$ to the tank water as a buffering agent. Water temperature was maintained at $28^{\circ} \pm 2^{\circ} \mathrm{C}$. Biofilters, siphoning and $20 \%$ weekly water exchange were sufficient to keep nitrite levels under $0.1 \mathrm{mg} / 1$ and ammonia under 0.5 $\mathrm{mg} / 1$ throughout the experiment. Ammonia, nitrites, and $\mathrm{pH}$ were measured with a Hach model FF-1A water analysis kit.

Eggs from spawners in treatment tanks were collected and enumerated by using a weight-subsampling method and grids on a petridish. Egg number was expressed as eggs per gram of female (epgf). Egg size (mm) was measured by using a micrometer and dissecting microscope.

Prawn eggs were classified into two stages. Early-stage eggs were those eggs in which the pigmented eye could not be seen. The color of these eggs ranged from bright yellow to orange. Late-stage eggs were those eggs in which a pigmented eye could be seen. The color of late-stage eggs was from dark orange to grey. 
Sukadi, M.F.

Females were tagged with an internal tag (Yano et al. 1986) so that spawning frequency could be traced throughout the experiment. Eggs were analyzed for total calcium content. The same numbers of eggs were taken from each of four prawns and pooled. Samples were then taken from the pooled eggs and dried for 24 hours at $100^{\circ} \mathrm{C}$. Dried samples were ashed (Lovell 1981) in a muffle furnace at $600^{\circ} \mathrm{C}$ for 3 hours. Total calcium determinations were made with an Inductively Coupled Argon Plasma Spectrometer, ICAP (Hue and Evans 1986).

Statistical computations to determine the effect of water hardness and egg stage on egg number per gram of female and on egg size were carried out using SAS General Linear Models for modified split-plot analysis. Three levels of water hardness were treated as whole plots and the two egg stages as sub-plots. Each treatment combination was applied in three replications. Randomized designs were used to determine the effects of water hardness on the number of spawnings per tank. Factorial experiments were used to determine the effects of water hardness and egg stage on egg calcium. Analysis of variance was applied to observations for number of spawnings per tank, spawning frequency, number of eggs per gram of female, egg sizes, and egg calcium. Differences among treatment means were examined by Duncan's test and selected contrasts (Steel and Torrie 1980; SAS 1985).

\section{Results and Discussion}

\section{Spawning}

Average number of spawnings per tank for the three treatments ranged from 23 for the $300 \mathrm{mg} / 1$ hardness to 27 for both the 150 and $18 \mathrm{mg} / 1$ hardness treatments (Table 1). Analysis of the data gave no evidence that the total

Table 1. Average spawns per tank during a 132-day period in water of 18,150 and $300 \mathrm{mg} / 1$ hardness. Tanks were $1.4 \mathrm{~m}^{3}$ and contained 30 female and 20 male prawns. All treatments had three replicates.

\begin{tabular}{cc}
\hline $\begin{array}{c}\text { Water Hardness, } \\
\left(\mathbf{m g} / \mathbf{1} \text { as } \mathrm{CaCO}_{3}\right)\end{array}$ & $\begin{array}{c}\left.\text { Total Spawns per Tank }{ }^{*}\right) \\
(\text { S.E. }=4.0)\end{array}$ \\
\hline 18 & $27.0^{\mathrm{a}}$ \\
150 & $27.0^{\mathrm{a}}$ \\
300 & $23.0^{\mathrm{a}}$ \\
\hline ") Values followed by the same letter are not statistically different $(\mathrm{P}>0.05)$
\end{tabular}


number of spawnings was related to water hardness $(P>0.05)$. The majority of spawnings (43\%) were from females in the weight range between 14.0 and 17.9 $\mathrm{g}$ (Figure 2). Spawning frequency decreased as size increased from $17.9 \mathrm{~g}$ to $33.9 \mathrm{~g}$. Split-plot analysis indicated that there were no significant differences between treatments for total number of spawners. However, the observed number of spawners decreased as water hardness increased (Table 2). There was no interaction between water hardness and spawning frequency of the prawns.

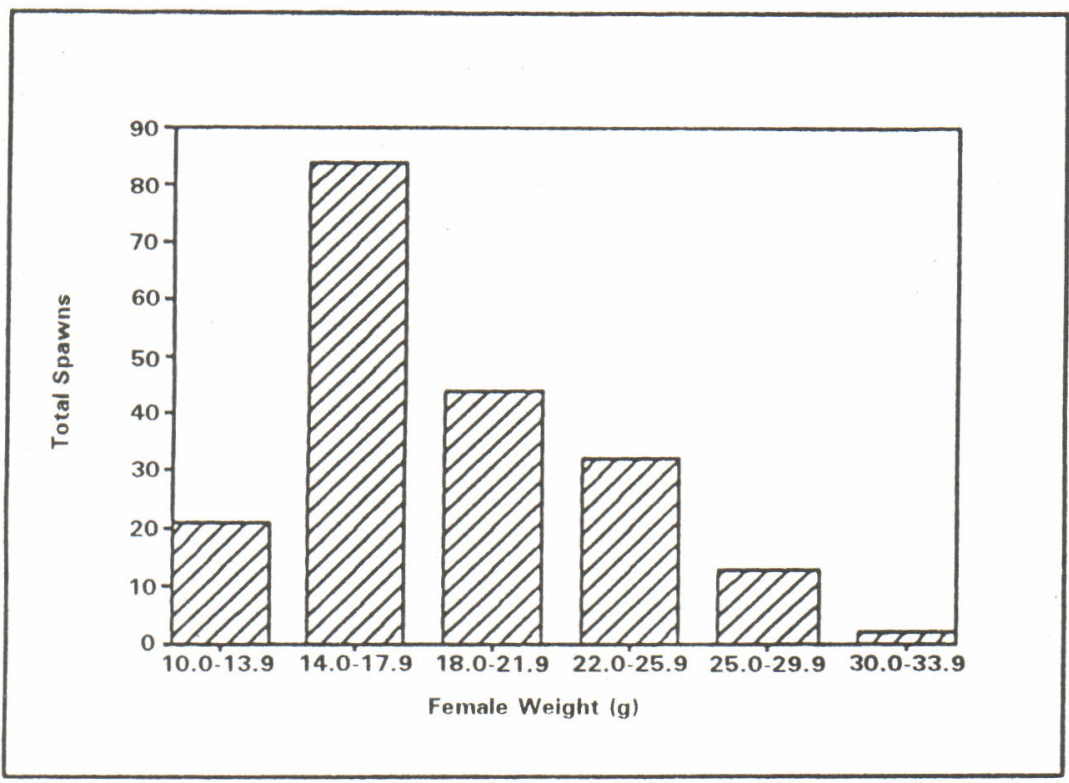

Figure 2. Relationship between female weight and total spawnings during a 132-day culture period. Total spawnings taken from all nine tanks $=232$.

The percentages of prawns which spawned once, twice, or three times during the 132-day study are reported in Table 2 . The number of non-spawners $(36.3 \%)$ and one-time spawners $(45.1 \%)$ were significantly greater than the number of prawns which spawned two or more times $(14.8,3.7 \%)(P<0.05)$.

Ling (1969) reported that under natural conditions in the tropics, female prawns may be able to spawn three to four times in one year. Three to four spawnings per year would result in a 90-120 day interval between each spawnings. In this spawning experiment, the prawns which spawned more than once $(18.5 \%)$ spawned at 44 to 46 -day intervals, or less than half the interval reported by Ling (1969). Wickins and Beard (1974) also reported 2 to 3 
Sukadi, M.F.

spawnings by a few individual prawns in a 170-day period. The process of maturing a new batch of oocytes in the ovaries, while the developing embryos were being carried by the female is possible (O'Donovan et al. 1984). The increased spawning frequency in this study may be a result of better nutrition and culture conditions.

Table 2. Reproductive performance (\%) of female prawn during a 132-day period while maintained in waters of 18,150 or $300 \mathrm{mg} / 1$ hardness. three replicates per treatment. Each tank contained 30 females and 20 males

\begin{tabular}{|c|c|c|c|c|}
\hline \multirow{2}{*}{$\begin{array}{l}\text { Number of } \\
\text { spawnings per } \\
\text { individual }\end{array}$} & \multicolumn{3}{|c|}{ Water Hardness (mg/1 as $\mathrm{CaCO}_{3}$ ) } & \multirow{2}{*}{$\begin{array}{c}\text { Means") } \\
\text { (S.E. }= \\
\text { 3.69) }\end{array}$} \\
\hline & 18 & 150 & 300 & \\
\hline \multicolumn{5}{|l|}{ Non-spawners: } \\
\hline $0 x$ & 30.1 & 37.8 & 41.1 & $36.3^{2}$ \\
\hline \multicolumn{5}{|l|}{ Multiple spawners: } \\
\hline $1 \mathrm{x}$ & 51.1 & 37.8 & 46.7 & $45.1^{2}$ \\
\hline $2 x$ & 16.6 & 20.0 & 7.8 & $14.8^{b}$ \\
\hline \multirow[t]{2}{*}{$3 x$} & 2.2 & 4.4 & 4.4 & $3.7^{c}$ \\
\hline & 69.6 & 62.2 & 58.9 & \\
\hline Total females (\%) & 100.0 & 100.0 & 100.0 & \\
\hline
\end{tabular}

") Values followed by the same letter are not statistically different $(P>0.05)$

\section{Egg Production}

\section{- Egg number}

The average number of eggs per gram of female (epgf) is shown in Table 3. There was no difference in epgf values between treatments and no interaction effects between water hardness and egg stage on epgf $(P>0.05)$.

The mean numbers of epgf early-and late-stage eggs differed significantly $(P<0.05)$. Early-Stage eggs averaged 721 epgf while the average number of late-stage eggs was 475 epgf, or a $34 \%$ decrease (Table 3 ).

Loss of prawn eggs during incubation has been reported by other authors (Wickins and Beard 1974; Balasundaram and Pandian 1982; Malecha 1983; and Mathavan and Murugadass 1988). Inbibiton of water and the consequent volumetric expansion of eggs, abrasion of eggs during the ventilatory movements of the pleopods, and erosion of individual territories are considered as some posible causes of the observed egg losses (Balasundaram and Pandian 1982). 
Table 3. Average number of eggs per gram of female (epgf) in water of 18 , 150 and $300 \mathrm{mg} / 1$ total hardness. Each treatment had three replicates

\begin{tabular}{|c|c|c|c|c|}
\hline \multirow{2}{*}{$\begin{array}{c}\text { Number of } \\
\text { spawnings } \\
\text { per } \\
\text { individual }\end{array}$} & \multicolumn{3}{|c|}{ Water Hardness (mg/l as $\mathrm{CaCO}_{3}$ ) } & \multirow{2}{*}{$\begin{array}{c}\left.\text { Means }^{*}\right) \\
(\text { S.E. = 3.69) }\end{array}$} \\
\hline & 18 & 150 & 300 & \\
\hline Early & 745 & 741 & 678 & 721 \\
\hline Late & 471 & 611 & 343 & 475 \\
\hline $\begin{array}{l}\text { Means: } \\
(\text { S.E. = 57) }\end{array}$ & 608 & 676 & 510 & \\
\hline
\end{tabular}

Malecha (1983) indicated that the number of eggs or spawning fecundity of $45 \mathrm{~g}$ females averaged 41,002 or around 911 epgf for early-stage eggs. Means of early-stage epgf in this study (721) were slightly lower than those shown by Malecha (1983). This smaller epgf is probably the result of both younger and smaller prawn broodstock. Both Malecha (1983) and Shakuntala (1977) state that fecundity was a linear function of body weight. All females in this study were less than $45 \mathrm{~g}$, with the most common size weighing 14-18 g.

\section{- Egg size}

There was a highly significant effect of egg stage on egg size $(\mathrm{P}<0.01)$. The average size of late-stage eggs was $0.651 \mathrm{~mm}$ in diameter while early-stage eggs were $0.575 \mathrm{~mm}$ in diameter. The size of late-stage eggs was negatively correlated with water hardness $(\mathrm{P}<0.05)$. Late-stage eggs decreased from 0.68 to $0.63 \mathrm{~mm}$ in diameter as water hardness increased from 18 to $300 \mathrm{mg} / \mathrm{l}$ (Figure 3). There was no interaction between water hardness and stage on egg size $(P>0.05)$.

Gonzal et al. (1987) found that if the incubation medium of silver carp (Hypophtalmichthys molitrix) had a lower ionic concentration (hypo-osmotic) than the egg, excessive water absorption and premature bursting of the egg might occur. Conversely, a hyper-osmotic medium caused dehydration and an actual decrease in egg size. The difference in ionic concentration caused by the difference in water hardness in this study is thought to have caused the decrease in observed mean late-stage egg size.

Davis (1959) found that egg membranes of the copepod, Diaptomus ashlandi became permeable to water in the late stages but that early-stage eggs were impermeable. This same change in egg membrane permeability may also occur 
Sukadi, M.F.

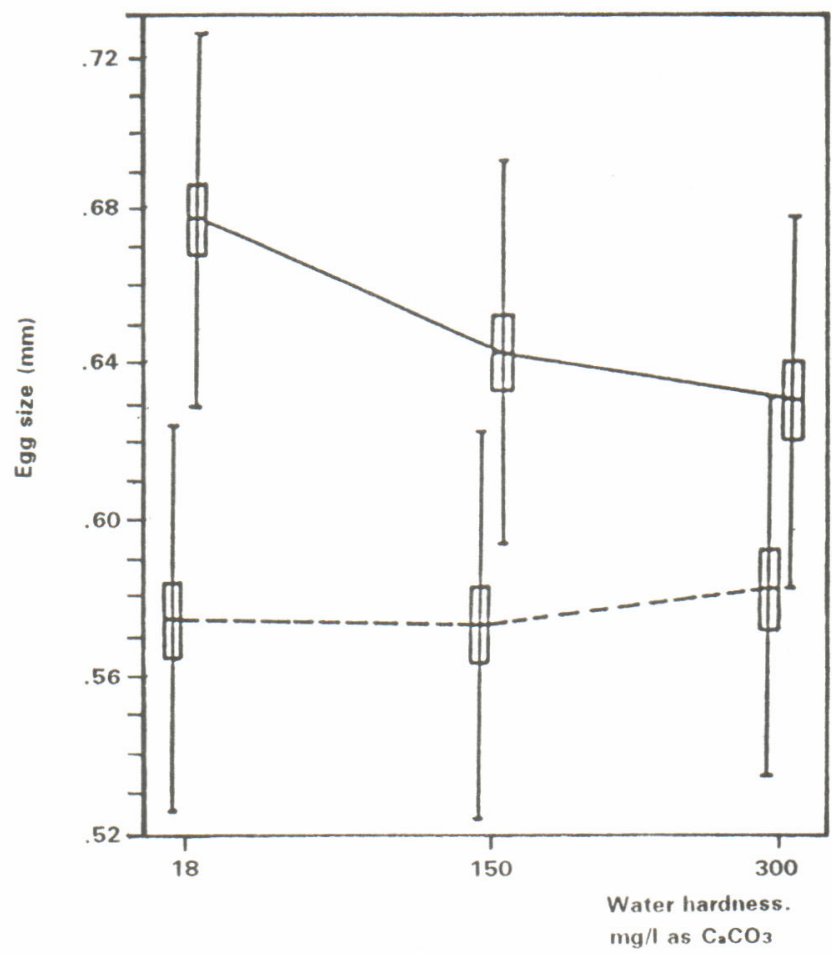

Figure 3. The size of early-stage eggs (broken-line) and late-stage eggs (solid-line) obtained from prawns in water of different hardnesses. The graphs show the mean \pm s.e. (vertical rectangle), and the range (vertical line). All treatments had three replicates.

in prawn egg membranes. In this study early-stage eggs were very similar in size $(0.572-0.577 \mathrm{~mm})$ at all hardness levels. Late-stage eggs varied in size (0.63-0.68 $\mathrm{mm})$ depending on water hardness.

\section{- Egg calcium}

In this study, calcium content in early-stage eggs did not differ between treatments $(P>0.05)$ but was significantly different in late-stage eggs $(P<0.05)$. There was also a significant interaction of water hardness and egg stage on egg calcium $(P<0.05)$. Calcium content changed quadratically with water hardness both in early- and in late-stage eggs $(P<0.05)$ (Figure 4$)$.

The data indicate that there was movement of calcium from the water into the late stage eggs and that this movement varied with the level of total hardness. The concentration of calcium in the eggs increased as water hardness 


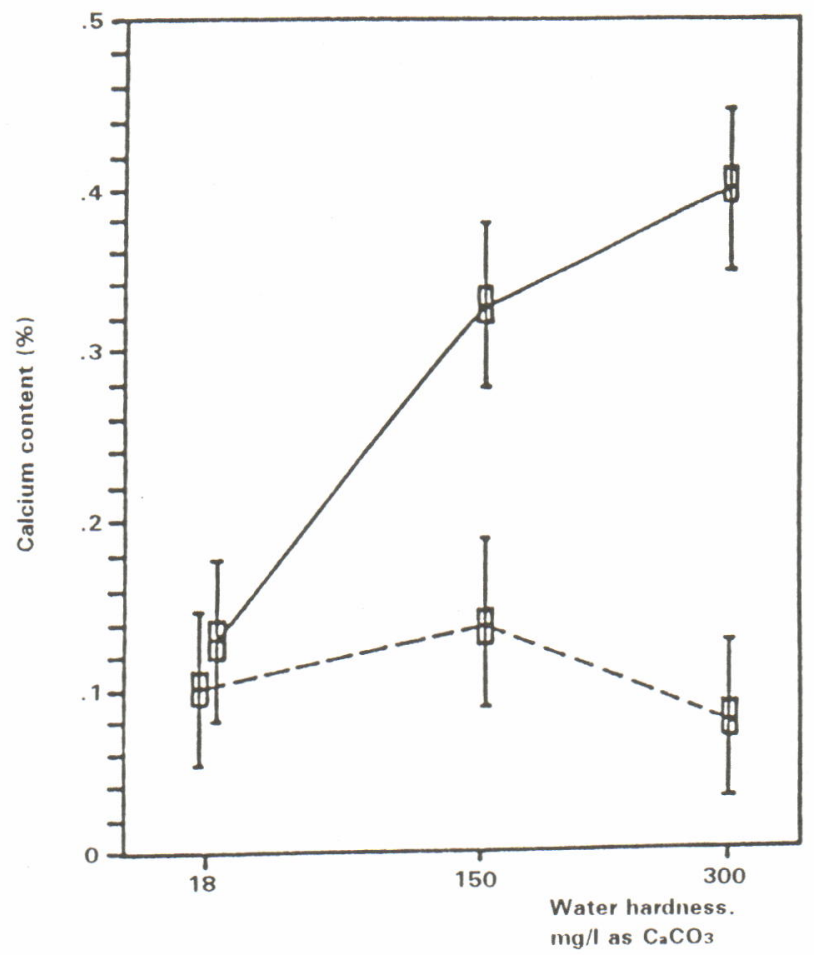

Figure 4. Calcium content of early-stage prawn eggs (broken-line) and late-stage prawn eggs (solid line) brooded in waters of different hardness. The graphs show the mean, the means \pm s.e. (Vertical rectangle), and the range (vertical line). All treatments had three replicates. Four prawns were used to provide eggs for each sample.

increased from 18 to $150 \mathrm{mg} / \mathrm{l}$. The calcium content in late-stage eggs in 150 and $300 \mathrm{mg} / \mathrm{l}$ water hardness was significantly higher than the calcium content in $18 \mathrm{mg} / 1(\mathrm{P}<0.05)$. Robertson (1941) mentioned that one of the properties of the calcium ions is to reduce the permeability of the cells to water. If calcium ions reduce prawn-egg-membrane permeability, this could explain the reduced rate of calcium increase between 150 and $300 \mathrm{mg} / 1$. It is possible that at the higher level of hardness the reduction of membrane permeability reduced the rate of movement of calcium into the eggs. The movement of calcium entry was found to continue but at a slower rate.

Lee and $\mathrm{Hu}$ (1983) stated that since eggs do not feed, required minerals for the embryo should come either from existing stored minerals or as absorbed minerals from the ambient water. Absorption of minerals from the environment has been observed in salmon (Salmo salar) eggs (Hayes et al. 1946). 
The same phenomena of changing membrane permeability observed in copepod eggs may also occur in prawn eggs. As prawn eggs near hatching during late-stage development, the membrane may became more permeable allowing an influx of minerals for exoskeleton development.

\section{Conclusion}

Total number of spawnings, number of spawnings per female, and number of eggs per gram of female (epgf) were not significantly different in water hardness treatments ranging from 18 to $300 \mathrm{mg} / 1$ as $\mathrm{CaCO}_{3}$. The majority of spawnings $(43 \%)$ were from females in the weight range between 14.0-17.9 $\mathrm{g}$. The proportion of non-spawners $(36.3 \%)$ and one-time spawners $(45.1 \%)$ were significantly greater than two- or three-times spawners $(\mathrm{P}<0.05)$.

The number of epgf was not significantly different by water hardness and ranged from 510 to 676 . The number of late-stage (475 epgf) was significantly reduced from that of early-stage (721 epgf).

Early-stage eggs were very similar in size, ranging from $0.572-0.577 \mathrm{~mm}$ in diameter at all hardness levels tested. The average size of late-stage eggs decreased from 0.68 to $0.63 \mathrm{~mm}$ in diameter as water hardness increased from 18 to $300 \mathrm{mg} / \mathrm{l}$. The difference in ionic concentration caused by the differences in water hardness is thought to have caused the decrease in observed mean size of late-stage eggs. An increase in membrane permeability in the late-stage eggs appeared to have occurred in the prawn egg.

The effect of water hardness and the interaction between water hardness and egg stage on egg calcium was significant. Calcium content changed quadratically with water hardness both in early- and in late-stage eggs $(\mathrm{P}<0.05)$. As prawn eggs appoached hatching, the increased membrane permeability allowed an influx of minerals such as calcium.

\section{Acknowledgments}

This research was conducted from October 22, 1987 - March 2, 1988 at the Fisheries Research Unit, Alabama Agricultural Experiment Station and was part of the dissertation (Sukadi 1989) submitted by the author to Department of Fisheries and Allied Aquaculture, Auburn University.

The author is grateful to Dr. D.B. Rouse, Dr. R.O. Smitherman, Dr. R.T. Lovell, Departement of Fisheries and Allied Aquaculture, and Dr. Ann $\mathrm{H}$. Williams, Departement of Zoology and Wildlife Science, and Dr. John C. Williams, Research Data Analysis, Auburn University for their critical review of this manuscript and for their support for this study. Financial support for this study was from the Agency for Agricultural Research and Development (AARD), Republic of Indonesia. 
IFR Journal I(1), 1995

\section{References}

Balasundaram, C. and T. J. Pandian. 1982. Egg loss during incubation in Macrobrachium nobilii (Henderson \& Mathai). J. Expt. Mar. Ecol.59: 289-299.

Boyd, C E. 1984. Water quality in warmwater fish ponds. Dept. Fisheries and Allied Aquacultures. Agricultural Experiment Station. Auburn University,

Boyd, C. E. and R. Wu. 1989. Uses of gypsum in aquaculture. Aquaculture'89 WAS Meeting Abstracts. February 12-16. Los Angeles.

Davis, C. C. 1959. Osmotic hatching in the eggs of some freshwater copepods. Biol. Bull. Mar. Biol. Lab., Woods Hole 116:15-29.

Gonzal, A. C., E. V. Aralar and J. MaF. Pavico. 1987.The Effects of water hardness on the hatching and viability of silver carp (Hypophthal-michthys molitrix) eggs. Aquaculture 64 (2): 111-118.

Hayes, F. R., D. A. Darcy and C. M. Sullivan. 1946. Changes in the inorganic constituents of developing salmon eggs. J. Biol. Chemistry: 621-631.

Hue, N. V. and C. E. Evans. 1986. Procedures used for soil and plant analysis by the Auburn University soil testing laboratory. Dept. of Agronomy and Soils. Dept. Series No. 106. Auburn University, Al.

Jenkins, N. K. and K. Simkiss. 1968. The calcium and phosphate metabolism of reproducing reptiles with particular reference to the adder (Vipera berus). Comp. Biochem. Physiol. Vol. 26:865-876.

Lee, C. S. and F. Hu. 1983. Influences of $\mathrm{Ca}$ and $\mathrm{mg}$ ions on the egg survival of grey mullet, Mugil cephalus L. J. Fish Biol. 22:13-20.

Ling, S. W. 1969. The General biology and development of Macrobrachium rosenbergii (de Man). FAO Fish. Rep. 57(3):589-606.

Lovell, R. T. 1981. Laboratory manual for fish feed analysis and fish nutrition studies. Int'l Center Aquacul. Auburn University.

Malecha, S. 1983. Commercial seed production of the freshwater prawn, Macrobrachium rosenbergii in Hawaii. In J. P. Mc Vey. CRC Handbook of maricul. Vol. I. Crustacean Aquaculture. CRC Press Inc. Boca Raton Florida: 205-229.

Mathavan, S. and S. Murugadass. 1988. An improved design for in vitro hatching of Macrobrachium eggs. Asian Fisheries Science 1(2):197-201.

O'Donovan, P., M. Abraham and D. Cohen. 1984. The ovarium cycle during the intermoult in ovigerous Macrobrachium rosenbergii. Aquaculture 36:347-358.

Robertson, J. D. 1941. The funtion and metabolism of calcium in the invertebrata. In H. M. Fox (Ed.). Biological Reviews of the Cambridge Philosophical Soc. 16:106-133.

Sandifer, P. A. and T. I. J. Smith. 1985. Freshwater prawns. In J. V. Huner and E. E. Brown (Eds). Crustacean and Mollusk Aquaculture in the United States. AVI Publ. Co. Inc. Connecticut:63-125. 
Sukadi, M.F.

SAS. 1985. SAS User's Guide: Statistics version 5 Edition. SAS Inst. Inc. N.C.

Shakuntala, K. 1977. The Relation between body size and number of eggs in the freshwater prawn, Macrobrachiumlamarrei (H. Milne Edwards) (Decapoda, Caridea). Crustaceana 33(1):17-22.

Simkiss, K. 1967. Calcium in reproductive physiology. A Comparative Study of Vertebrates. Modern Biological Studies. Reinhold Publ. Co.

Steel, R. G. D. and J. H. Torrie. 1980. Principles and procedures of statistics. McGrawHill Book Co.

Sukadi, M.F. 1989. Responses of the freshwater prawn, Macrobrachium rosenbergii to different levels of water hardness and dietary calcium. Ph.D. Disertation. Auburn Univ. Aubur AL.

Wickins, J. F. and T. W. Beard. 1974. Observations on the breeding and growth of the giant freshwater prawn, Macrobrachium rosenbergii (de Man) in the laboratory. Aquaculture 3:159-174.

Yano, I., J. N. Sweeney, C. S. Tamaru and J. A. Wyban. 1986. Internal tagging method for individual identification of penaeid shrimp. Brief Tech. Note. (Unpublished). 